\title{
Substituição do grão de milho pelo grão de milheto em dietas contendo silagem de milho ou silagem de capim-elefante na alimentação de bovinos de corte
}

\author{
José Renato Silva Gonçalves ${ }^{1}$, Alexandre Vaz Pires ${ }^{2}$, Ivanete Susin², Laísse Garcia de Lima ${ }^{1}$, \\ Clayton Quirino Mendes ${ }^{3}$, Evandro Maia Ferreira ${ }^{3}$
}

\footnotetext{
1 Estação Experimental Agrozootécnica Hildegard G. von Pritzelwitz, Fazenda Figueira, Londrina, PR.

2 Departamento de Zootecnia, ESALQ/USP, Piracicaba, SP.

3 Programa de Pós-Graduação em Ciência Animal e Pastagens, ESALQ/USP, Piracicaba, SP.
}

RESUMO - O objetivo neste trabalho foi avaliar os efeitos da substituição do grão de milho pelo grão de milheto em dietas contendo silagem de milho ou de capim-elefante sobre o consumo, a digestibilidade aparente dos nutrientes e os parâmetros ruminais de bovinos de corte. Seis novilhos da raça Nelore, providos de cânula ruminal, foram distribuídos em quadrado latino $6 \times 6$, em arranjo fatorial $2 \times 3$, com duas fontes de volumoso (silagem de milho ou silagem de capim-elefante) e três níveis de substituição do grão de milho pelo grão de milheto (0, 50 ou 100\%). A substituição do grão de milho pelo grão de milheto e as fontes de volumoso não influenciaram o consumo de nutrientes. Entretanto, a utilização da silagem de capim-elefante aumentou o consumo de fibra em detergente ácido e reduziu o consumo de amido em comparação às dietas contendo silagem de milho. Não houve efeito da substituição do grão de milho pelo grão de milheto sobre a digestibilidade de matéria seca, matéria orgânica, proteína bruta, fibra em detergente neutro e fibra em detergente ácido. Contudo, houve aumento da digestibilidade do extrato etéreo, e os maiores valores foram observados para as dietas contendo 50 e $100 \%$ de grão de milheto em relação às dietas contendo $100 \%$ de grão de milho, independentemente da fonte de volumoso. A digestibilidade do amido também aumentou com a substituição do grão de milho pelo grão de milheto. A fonte de volumoso influenciou a digestibilidade da fibra em detergente neutro e da fibra em detergente ácido, que aumentou com a utilização da silagem de capim-elefante. A substituição do grão de milho pelo grão de milheto na dieta reduz a concentração ruminal de amônia sem alterar a concentração de acetato, propionato, ácidos graxos voláteis totais e o pH ruminal. A utilização de silagem de capim-elefante aumenta a concentração ruminal de acetato e a relação acetato:propionato.

Palavras-chave: ácidos graxos voláteis, amônia ruminal, digestibilidade, pH ruminal, ruminantes

\section{Replacement of corn grain by pearl millet grain in diets containing corn or elephant grass silage fed beef cattle}

\footnotetext{
ABSTRACT - The objective of this experiment was to evaluate the effects of replacing corn grain by pearl millet grain in diets containing corn silage or elephant grass silage on feed intake, apparent digestibility of nutrients and ruminal parameters of beef cattle. Six cannulated Nellore steers were distributed in a $6 \times 6$ Latin square, in a $2 \times 3$ factorial scheme, with two sources of roughages (corn silage or elephant grass silage) and three levels of replacement of corn grain by pearl millet grain (0, 50 or 100\%). Replacement of corn grain by pearl millet grain and the roughage sources did not affect nutrient intake. However, the use of elephant grass silage increased acid detergent fiber and decreased starch intake when compared to diets containing corn silage. There was no effect of replacement of corn grain by pearl millet grain on digestibilities of dry matter, organic matter, crude protein, neutral detergent fiber and acid detergent fiber. However, there was an increase of digestibility of ether extract and the highest values were observed for diets containing 50 and $100 \%$ of pearl millet grain in relation to diets containg $100 \%$ corn grain, regardless to roughage source. Digestibility of starch was also increased by the replacement of corn grain by pearl millet grain. Roughage source also had an effect on neutral and acid detergent fiber digestibilities, which increased with the use of elephant grass silage. Replacement of corn grain by pearl millet grain in the diet decreases ruminal ammonia concentration without changing concentrations of ruminal acetate, propionate, total volatile fatty acids and ruminal $\mathrm{pH}$. The use of elephant grass silage increases ruminal acetate concentration and acetate:propionate ratio.
}

Key Words: digestibility, ruminal ammonia, ruminal $\mathrm{pH}$, ruminants, volatile fatty acids 


\section{Introdução}

A suplementação alimentar com dietas contendo silagem de milho e grãos de cereais nobres, como o grão de milho, eleva o custo de produção de bovinos no período de escassez de forragens, o que cria a necessidade de fontes alternativas de alimentos para ruminantes nesse período. Dentre as fontes alimentares com potencial para uso, pode-se destacar o capim-elefante para a produção de silagem, os coprodutos das indústrias de transformação de alimentos e os grãos obtidos de culturas anuais secundárias, como o sorgo e o milheto.

O capim-elefante é uma forrageira com excelente potencial de produção, podendo produzir até 14,5 t de MS/ha em 56 dias de rebrotação (Lima et al., 2007). Entretanto, o elevado teor de umidade e a baixa disponibilidade de carboidratos solúveis por ocasião do corte podem limitar a disponibilidade de substratos para os microrganismos produtores de ácido lático e afetar sua qualidade nutricional. Desse modo, a inclusão de aditivos absorventes de umidade e fornecedores de carboidratos solúveis pode melhorar o padrão fermentativo de silagens de capimelefante (Ferrari Jr. et al., 2009).

O milheto (Pennesetum americanum (L.)) é uma forrageira anual de verão, que pode ser utilizada tanto para a produção de forragem quanto para a produção de grãos. No Brasil, é produzido principalmente em sistema de plantio direto, geralmente em sucessão ao cultivo da soja. Essa característica faz com que em algumas épocas do ano ocorra grande disponibilidade de grãos para comercialização, com preços relativamente baixos, devido ao baixo custo de produção. De acordo com os dados apresentados por Ribeiro et al. (2004), o teor de amido do grão de milheto é $10 \%$ inferior ao do grão de milho (62\% x 72\% da MS), o que pode alterar o padrão de fermentação ruminal das dietas com a substituição do grão de milho pelo grão de milheto. O conhecimento da utilização do grão de milheto na alimentação de ruminantes pode viabilizar a sua inclusão como fonte de amido em dietas utilizadas em sistemas intensivos ou semi-intensivos de produção.

O objetivo neste trabalho foi avaliar os efeitos da substituição do grão de milho pelo grão de milheto em dietas contendo silagem de milho ou silagem de capim-elefante sobre o consumo, a digestibilidade aparente dos nutrientes e os parâmetros ruminais de bovinos de corte.

\section{Material e Métodos}

O experimento foi realizado nas instalações para ensaio de metabolismo com bovinos do Departamento de
Zootecnia, da Escola Superior de Agricultura "Luiz de Queiroz”, em Piracicaba, São Paulo.

Foram utilizados seis novilhos da raça Nelore, providos de cânula no rúmen, com peso médio inicial de 250 kg. Os animais foram alojados individualmente em baias cobertas do tipo tie stall, com piso emborrachado, comedouro e bebedouro. O período experimental teve duração de 84 dias, divididos em seis subperíodos de 14 dias, dos quais 10 dias foram destinados à adaptação dos animais às dietas experimentais e às instalações e quatro dias, para a mensuração do consumo de ração e para colheita de amostras das dietas ofertadas, sobras, fezes e do fluido ruminal.

As dietas foram arranjadas em esquema fatorial $2 \times 3$, com duas fontes de volumoso (silagem de milho ou silagem de capim-elefante) e três níveis de substituição do grão de milho pelo grão de milheto (0, 50 ou 100\%) para cada fonte de volumoso avaliada (Tabela 1$)$.

As silagens de milho e de capim-elefante foram confeccionadas em silos do tipo trincheira. As plantas inteiras de milho ou de capim-elefante foram cortadas e picadas mecanicamente, sendo a picadora regulada para cortar a forragem em partículas de $2 \mathrm{~cm}$. O capim-elefante picado foi misturado com $13 \%$ de polpa cítrica, com base no peso de matéria úmida da forragem, e homegeneizado em vagão forrageiro. Ambos os volumosos foram ensilados e compactados mecanicamente com auxílio de trator.

Durante o período experimental, as dietas foram pesadas diariamente e ofertadas ad libitum às 6h30min e às 18h30min. A quantidade ofertada foi ajustada com base no consumo do dia anterior, não se permitindo sobras superiores a $10 \%$. Do $11^{\circ}$ ao $14^{\circ}$ dia de cada período experimental, as sobras foram pesadas para a determinação do consumo. No mesmo período, duas vezes ao dia (6h30min e 18h30min), foi realizada a coleta total das fezes, as quais foram quantificadas para posterior cálculo da digestibilidade aparente dos nutrientes. Foi amostrado 10\% de cada dieta ofertada, das sobras e das fezes, as quais foram compostas por animal e por período experimental e armazenadas a $-20^{\circ} \mathrm{C}$.

Após o término do experimento, as amostras foram descongeladas e secas em estufa de ventilação forçada à temperatura de $55^{\circ} \mathrm{C}$ por 72 horas. Em seguida, foram moídas em moinho tipo Wiley com peneiras com crivos de $1 \mathrm{~mm}$ e analisadas para a determinação da matéria seca, da matéria mineral, da proteína bruta e do extato etéreo, de acordo com a AOAC (1997), da fibra em detergente neutro e da fibra em detergente ácido, conforme Van Soest et al. (1991). O teor de amido foi determinado conforme metodologia descrita por Poore et al. (1989), em que o amido sofre processo de hidrólise enzimática e a glicose resultante é mensurada. A glicose foi determinada por meio de leitura direta em 
Tabela 1 - Composição das dietas experimentais (\%MS)

\begin{tabular}{|c|c|c|c|c|c|c|}
\hline \multirow[t]{3}{*}{ Item } & \multicolumn{6}{|c|}{ Dieta experimental } \\
\hline & \multicolumn{3}{|c|}{ Silagem de milho } & \multicolumn{3}{|c|}{ Silagem de capim-elefante ${ }^{1}$} \\
\hline & $\begin{array}{l}0 \% \text { grãos } \\
\text { de milheto }\end{array}$ & $\begin{array}{l}50 \% \text { grãos } \\
\text { de milheto }\end{array}$ & $\begin{array}{l}100 \% \text { grãos } \\
\text { de milheto }\end{array}$ & $\begin{array}{c}\text { 0\% grãos } \\
\text { de milheto }\end{array}$ & $\begin{array}{l}50 \% \text { grãos } \\
\text { de milheto }\end{array}$ & $\begin{array}{l}100 \% \text { grãos } \\
\text { de milheto }\end{array}$ \\
\hline \multicolumn{7}{|l|}{ Ingrediente } \\
\hline Silagem de milho & 40,0 & 40,0 & 40,0 & - & - & - \\
\hline Silagem de capim-elefante & - & - & - & 40,0 & 40,0 & 40,0 \\
\hline Farelo de soja & 7,0 & 4,3 & 1,3 & 7,0 & 4,3 & 1,3 \\
\hline Caroço de algodão & 15,0 & 15,0 & 15,0 & 15,0 & 15,0 & 15,0 \\
\hline Ureia & 0,5 & 0,5 & 0,5 & 0,5 & 0,5 & 0,5 \\
\hline Minerais e vitaminas & 2,0 & 2,0 & 2,0 & 2,0 & 2,0 & 2,0 \\
\hline \multicolumn{7}{|l|}{ Nutriente } \\
\hline Amido & 32,5 & 30,5 & 34,5 & 25,8 & 25,9 & 27,4 \\
\hline ELg, Mcal $/ \mathrm{kg}^{2}$ & 1,3 & 1,2 & 1,2 & 1,2 & 1,1 & 1,1 \\
\hline
\end{tabular}

${ }^{1}$ Ensilada com $13 \%$ de polpa cítrica com base na matéria úmida.

2 Energia líquida para ganho, estimada utilizando o Nutrient Research Council - NRC (1996).

autoanalisador bioquímico (YSI 2700 Select, Biochemistry Analyser, Yellow Spring, Oh, USA). O teor de amido foi determinado por meio da curva-padrão de regressão obtida pelas concentrações de glicose conhecida. A matéria orgânica foi calculada pela diferença entre a matéria seca e a matéria mineral.

Amostras contendo $200 \mathrm{~mL}$ do conteúdo ruminal foram colhidas no $11^{\circ}$ e no $12^{\circ}$ dia de cada sub-período experimental. As colheitas tiveram início às $6 \mathrm{~h} 30 \mathrm{~min}$, imediatamente antes do fornecimento das dietas (tempo zero), sendo as demais colheitas realizadas 2, 4, 6, 8 e 10 horas após o fornecimento das dietas. Imediatamente após a colheita do fluido ruminal, o pH foi determinado, utilizando-se potenciômetro digital (DIGIMED ${ }^{\circledR}$ DM20). Em seguida, duas alíquotas de $25 \mathrm{~mL}$ do fluido ruminal foram armazenadas em frascos plásticos contendo $1,25 \mathrm{~mL}$ de ácido clorídrico e congeladas a $-20^{\circ} \mathrm{C}$ para posterior análise dos ácidos graxos voláteis (AGV) e nitrogênio amoniacal $\left(\mathrm{N}-\mathrm{NH}_{3}\right)$.

A concentração dos ácidos graxos voláteis foi determinada conforme metodologia descrita por Campos et al. (2004). Depois de descongeladas, as amostras do fluído ruminal foram centrifugadas a $15.000 \mathrm{x} \mathrm{g}$ a $4^{\circ} \mathrm{C}$ por 60 minutos e analisadas em cromatógrafo líquido-gasoso (Hewlett Packard 5890 Series II GC) equipado com integrador (Hewlett Packard 3396 Series II Integrator) e injetor automático (Hewlett Packard 6890 Series Injector). O padrão interno utilizado foi o ácido 2-metilbutírico, sendo acrescentado, em cada tubo para leitura no cromatógrafo, um volume de $100 \mu \mathrm{L}$ do padrão interno, $800 \mu \mathrm{L}$ da amostra e $200 \mu \mathrm{L}$ de ácido fórmico. Uma mistura de ácidos graxos voláteis com concentração conhecida foi utilizada como padrão externo para a calibração do equipamento.

A análise de $\mathrm{N}-\mathrm{NH}_{3}$ foi realizada pelo método colorimétrico descrito por Chaney \& Marbach (1962), adaptado para leitura em leitor de microplaca (BIO - RAD, Hercules, CA, EUA), utilizando-se filtro para absorbância de $550 \mathrm{~nm}$ (Campos et al., 2004).

O delineamento experimental utilizado foi em quadrado latino $6 \times 6$, sendo seis dietas e seis períodos experimentais. Os dados foram analisados pelo procedimento GLM do SAS (1999). As médias foram obtidas pelo comando LSMEANS e o teste Tukey foi aplicado quando se detectou efeito das dietas experimentais $(\mathrm{P}<0,05)$.

\section{Resultados e Discussão}

Não houve interação das fontes de volumoso e de concentrado sobre o consumo de nutrientes (Tabela 2). A substituição do grão de milho pelo grão de milheto, assim como as fontes de volumoso avaliadas, não alteraram o consumo de matéria seca, matéria orgânica, proteína bruta, extrato etéreo e fibra em detergente neutro. Entretanto, a utilização da silagem de capim-elefante aumentou $(\mathrm{P}<0,05)$ o consumo de fibra em detergente ácido e reduziu $(\mathrm{P}<0,05)$ o consumo de amido, comparado ao uso da silagem de milho. O aumento no consumo dessa fração fibrosa com a 
Tabela 2 - Consumo de nutrientes das dietas experimentais

\begin{tabular}{|c|c|c|c|c|c|c|c|c|c|}
\hline \multirow[t]{2}{*}{ Item } & \multicolumn{8}{|c|}{ Dieta experimental } & \multirow[t]{2}{*}{$\mathrm{EPM}^{1}$} \\
\hline & $\begin{array}{l}0 \% \text { grãos } \\
\text { de milheto }\end{array}$ & $\begin{array}{l}50 \% \text { grãos } \\
\text { de milheto }\end{array}$ & $\begin{array}{l}100 \% \text { grãos } \\
\text { de milheto }\end{array}$ & Média & $\begin{array}{l}0 \% \text { grãos } \\
\text { de milheto }\end{array}$ & $\begin{array}{l}50 \% \text { grãos } \\
\text { de milheto }\end{array}$ & $\begin{array}{l}100 \% \text { grãos } \\
\text { de milheto }\end{array}$ & Média & \\
\hline Matéria seca & 6,5 & 5,4 & 6,1 & 6,0 & 6,2 & 5,8 & 5,7 & 5,9 & 0,39 \\
\hline Matéria orgânica & 6,2 & 5,1 & 5,7 & 5,7 & 5,7 & 5,3 & 5,3 & 5,4 & 0,36 \\
\hline Fibra em detergente neutro & 1,9 & 1,7 & 1,9 & 1,8 & 1,9 & 1,9 & 1,9 & 1,9 & 0,12 \\
\hline Fibra em detergente ácido & 1,0 & 0,9 & 1,0 & 1,0 & 1,2 & 1,2 & 1,2 & 1,2 & 0,07 \\
\hline Amido & 2,1 & 1,6 & 1,9 & 1,9 & 1,6 & 1,4 & 1,4 & 1,5 & 0,14 \\
\hline
\end{tabular}

${ }^{1}$ EPM: erro-padrão da média.

utilização da silagem de capim-elefante provavelmente ocorreu pelo fato desse volumoso apresentar maior teor de tal componente em relação à silagem de milho, o que está de acordo com Queiroz et al. (2008) e Zanine et al. (2007), os quais verificaram para silagem de milho e de capim-elefante valores de fibra em detergente ácido de 29,9 e 33,0\%, respectivamente.

O menor consumo de amido pelos animais que receberam as dietas contendo silagem de capim-elefante foi devido ao maior teor de amido presente na silagem de milho, em função da presença dos grãos, o que consequentemente propiciou a maior concentração de amido verificada nas dietas contendo essa silagem (Tabela 1). A ausência de efeito das fontes de volumoso sobre o consumo de matéria seca é satisfatório para a silagem de capimelefante e reflete que esta foi adequadamente conservada, o que pode estar relacionado a melhorias nos padrões de fermentação do material no silo com a adição de $13 \%$ de polpa cítrica. Esta tem ação comprovada em reduzir a atividade da água livre, limitar a ação de bactérias do gênero Clostridium e elevar o teor de açúcares na massa ensilada, facilitando o estabelecimento das bactérias ácido-láticas (Bernardes et al., 2005).
O consumo similar de matéria seca pelos animais alimentados com grão de milho ou grão de milheto demonstra que este apresenta aceitação pelos animais semelhante ao grão de milho, o que sugere que não há diferença de palatabilidade entre as duas fontes de amido. Semelhantemente ao observado nesse trabalho, Ribeiro et al. (2004) substituiram totalmente o grão de milho pelo grão de milheto em dietas para vacas leiteiras e, também, não verificarm efeito sobre o consumo de matéria seca.

Não houve interação das fontes de volumoso e de concentrado sobre a digestibilidade dos nutrientes (Tabela 3). A substituição do grão de milho pelo grão de milheto não alterou a digestibilidade aparente da matéria seca, da matéria orgânica, da proteína bruta, da fibra em detergente neutro e da fibra em detergente ácido. Entretanto, a digestibilidade do amido aumentou à medida que o grão de milho foi substituído pelo grão de milheto. A maior digestibilidade do amido das dietas que continham grãos de milheto provavelmente foi devido à sua maior digestão no intestino delgado, haja vista que a concentração ruminal de propionato, utilizada como indicador de digestão ruminal do amido (Poore et al., 1993), não diferiu entre as dietas (Tabela 4).

Tabela 3 - Digestibilidade aparente total dos nutrientes das dietas experimentais

\begin{tabular}{|c|c|c|c|c|c|c|c|c|c|}
\hline \multirow[t]{2}{*}{ Item } & \multicolumn{8}{|c|}{ Dieta experimental } & \multirow[t]{2}{*}{$\mathrm{EPM}^{1}$} \\
\hline & $\begin{array}{l}0 \% \text { grãos } \\
\text { de milheto }\end{array}$ & $\begin{array}{l}50 \% \text { grãos } \\
\text { de milheto }\end{array}$ & $\begin{array}{l}100 \% \text { grãos } \\
\text { de milheto }\end{array}$ & Média & $\begin{array}{l}0 \% \text { grãos } \\
\text { de milheto }\end{array}$ & $\begin{array}{l}50 \% \text { grãos } \\
\text { de milheto }\end{array}$ & $\begin{array}{l}100 \% \text { grãos } \\
\text { de milheto }\end{array}$ & Média & \\
\hline Matéria seca & 63,0 & 63,4 & 65,4 & 63,9 & 65,0 & 64,9 & 68,0 & 66,0 & 2,13 \\
\hline Matéria orgânica & 64,5 & 65,8 & 67,1 & 65,8 & 67,2 & 67,3 & 70,4 & 68,3 & 2,02 \\
\hline Proteína bruta & 66,2 & 65,3 & 67,4 & 66,3 & 67,7 & 66,6 & 67,5 & 67,3 & 2,51 \\
\hline Fibra em detergente ácido & 37,4 & 39,6 & 35,9 & 37,6 & 48,7 & 52,3 & 53,3 & 51,4 & 3,62 \\
\hline Amido & $86,3 c$ & $91,0 \mathrm{~b}$ & $94,6 \mathrm{a}$ & 90,6 & $88,3 c$ & $92,0 \mathrm{~b}$ & 96,8 a & 92,4 & 1,54 \\
\hline
\end{tabular}

${ }^{1}$ EPM: erro-padrão da média;

abc - Médias seguidas de letras iguais, na mesma linha e dentro de cada fonte de volumoso não diferem $(P>0,05)$. 
Tabela 4 - Parâmetros ruminais dos bovinos alimentados com as dietas experimentais

\begin{tabular}{|c|c|c|c|c|c|c|c|c|c|c|}
\hline \multirow[t]{3}{*}{ Item } & \multicolumn{7}{|c|}{ Dieta experimental } & \multirow[b]{3}{*}{ Média } & \multicolumn{2}{|c|}{$\mathrm{P}^{1}$} \\
\hline & \multicolumn{3}{|c|}{ Silagem de milho } & \multirow[b]{2}{*}{ Média } & \multicolumn{3}{|c|}{ Silagem de capim-elefante } & & \multirow[b]{2}{*}{$\mathrm{H}$} & \multirow[b]{2}{*}{$\mathrm{D} * \mathrm{H}$} \\
\hline & $\begin{array}{c}0 \% \text { grãos } \\
\text { de milheto }\end{array}$ & $\begin{array}{l}50 \% \text { grãos } \\
\text { de milheto }\end{array}$ & $\begin{array}{l}100 \% \text { grãos } \\
\text { de milheto }\end{array}$ & & $\begin{array}{l}0 \% \text { grãos } \\
\text { de milheto }\end{array}$ & $\begin{array}{l}50 \% \text { grãos } \\
\text { de milheto }\end{array}$ & $\begin{array}{l}100 \% \text { grãos } \\
\text { de milheto }\end{array}$ & & & \\
\hline Acetato, mM & 50,3 & 49,4 & 45,0 & 48,2 & 59,0 & 57,6 & 58,0 & 58,2 & $<0,05$ & NS \\
\hline Propionato, mM & 17,1 & 16,2 & 14,0 & 15,8 & 14,4 & 14,7 & 14,2 & 14,4 & $<0,05$ & NS \\
\hline Butirato, mM & $4,1 \mathrm{ab}$ & $4,5 \mathrm{a}$ & $3,2 b$ & 3,9 & 4,5 & 4,6 & 4,8 & 4,6 & $<0,05$ & NS \\
\hline Ácidos graxos totais, mM & 71,5 & 70,1 & 62,3 & 68,0 & 78,0 & 76,8 & 76,9 & 77,2 & NS & NS \\
\hline Acetato:propionato & $3,0 \mathrm{~b}$ & $3,1 \mathrm{ab}$ & $3,2 \mathrm{a}$ & 3,1 & 4,1 & 4,0 & 4,1 & 4,1 & $<0,05$ & NS \\
\hline Amônia, mg/dL & $18,6 \mathrm{a}$ & $13,8 b$ & $11,8 \mathrm{~b}$ & 14,7 & $21,1 \mathrm{a}$ & $15,9 b$ & $16,9 b$ & 18,0 & NS & NS \\
\hline $\mathrm{pH}$ & 6,3 & 6,4 & 6,4 & 6,4 & 6,4 & 6,5 & 6,4 & 6,4 & $<0,05$ & NS \\
\hline
\end{tabular}

${ }^{1} \mathrm{P}$ : probabilidade de haver efeito entre as dietas experimentais, sendo H: efeito de horas após a alimentação; D*H: efeito da interação dietas $\times$ horas após a alimentação. ab - Médias seguidas de letras iguais, na mesma linha e dentro de cada fonte de volumoso, não diferem $(P>0,05)$.

Houve aumento na digestibilidade do extrato etéreo, sendo os maiores valores observados nas dietas contendo $50 \%$ e $100 \%$ de grão de milheto em relação às dietas contendo $100 \%$ de grão de milho, independentemente da fonte de volumoso. Os resultados apresentados na literatura não são conclusivos a respeito desse efeito. Hill \& Hanna (1990) trabalharam com bovinos de corte e verificaram digestibilidade similar do extrato etéreo em dietas contendo grãos de milho ou de milheto. Por outro lado, Hill et al. (1996) verificaram redução na digestibilidade da fração lipídica com a inclusão do grão de milheto em substituição ao grão de milho. As razões para tais variações podem estar relacionadas a diferenças na composição dos grãos utilizados, no consumo de matéria seca pelos animais e nos teores de inclusão dos grãos nas dietas.

A substituição do grão de milho pelo grão de milheto não alterou a concentração ruminal de acetato (Tabela 4). Entretanto, houve efeito da fonte de volumoso, sendo observada maior concentração de acetato no líquido ruminal dos animais alimentados com as dietas contendo silagem de capim-elefante. Para essa variável, houve efeito de horas e não foi observada interação entre dietas e horas (Figura 1a). O aumento na concentração ruminal de acetato ocorreu em função da maior digestibilidade da fibra em detergente neutro com a utilização da silagem de capim-elefante(Tabela3), visto que, de acordo com Firkins et al. (2006), o acetato é o principal ácido graxo oriundo da digestão da fibra.

A concentração de propionato não foi influenciada pelas fontes de amido e de volumoso. Adicionalmente, não foi verificada interação entre dietas e horas. Contudo, verificou-se efeito de horas, sendo que a máxima concentração de propionato ocorreu entre 4 e 6 horas após o fornecimento das dietas (Figura 1b). Tais resultados, assim como os obtidos por Ribeiro et al. (2004), reforçam a hipótese de que as fontes de amido utilizadas apresentaram padrão de degradação ruminal semelhante.
Houve interação entre as fontes de volumoso e de amido sobre a relação acetato:propionato. Quando a fonte de volumoso utilizada foi a silagem de capim-elefante, não houve diferença na relação acetato:propionato com a substituição do grão de milho pelo grão de milheto. Contudo, foi observada maior relação acetato:propionato para a dieta contendo $100 \%$ de grão de milheto, tendo a silagem de milho como volumoso. Comparando as fontes de volumoso, os animais alimentados com as dietas contendo silagem de capim-elefante apresentaram maior relação acetato:propionato, o que pode ser atribuída à maior concentração de acetato produzida com a utilização desse volumoso. De modo semelhante ao verificado para a evolução temporal da concentração de acetato e de propionato, a relação acetato:propionato também foi alterada pelas horas após alimentação, não sendo verificada interação entre dietas e horas (Figura 1c).

Os animais alimentados com as dietas contendo silagem de capim-elefante apresentaram maior concentração ruminal de ácidos graxos voláteis totais. Não houve efeito das fontes de amido para esse parâmetro, independentemente da fonte de volumoso utilizada (Tabela 4). Os picos nas concentrações dos ácidos graxos voláteis totais ocorreram entre 4 e 8 horas após o fornecimento das dietas. Verificou-se efeito de horas, não havendo interação entre dietas e horas (Figura 1d).

A concentração ruminal de butirato não foi influenciada pelas horas após a alimentação, bem como não houve interação entre dietas e horas (Figura 1e). Entretanto, verificou-se interação entre as fontes de volumoso e de amido sobre a concentração ruminal de butirato, sendo que nas dietas contendo a silagem de capim-elefante não houve efeito da substituição do grão de milho pelo grão de milheto. Por outro lado, quando o volumoso utilizado foi a silagem de milho, verificou-se menor concentração de butirato para a dieta contendo $100 \%$ de grão de milheto (Tabela 4). Entre 


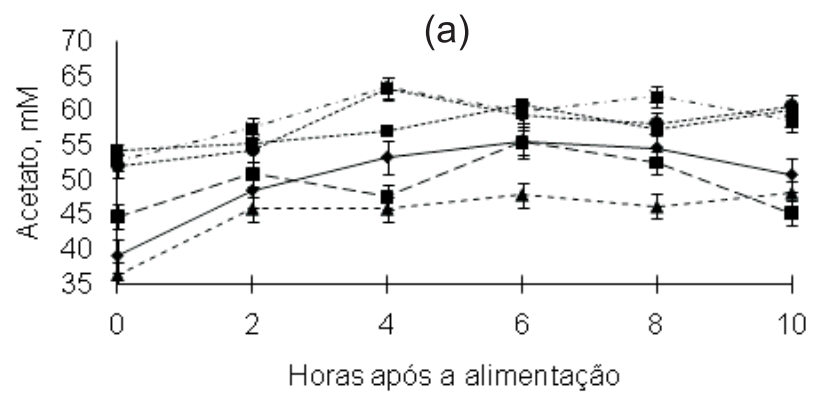

$$
\begin{aligned}
& \multimap 0 \text { OGMSM --50GMSM ---100GMSM } \\
& \cdots \text { OGMSC …50GMSC -..100GMSC }
\end{aligned}
$$

(c)
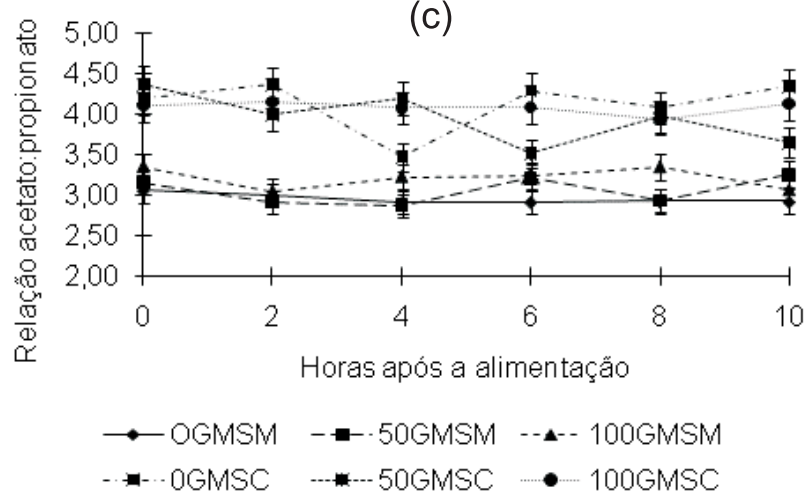

(e)

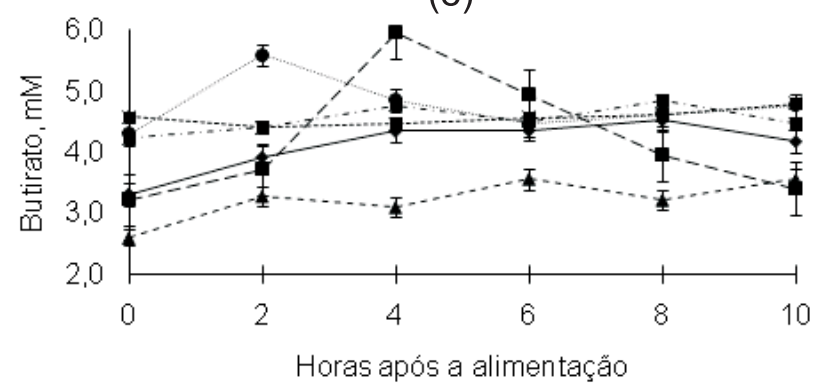

$\begin{array}{lll}\longrightarrow 0 \text { OGMSM } & -50 \text { GMSM } & \cdots 100 \text { GMSM } \\ \cdots \text { OGMSC } & -50 \text { MSC } & \bullet 100 \text { GMSC }\end{array}$

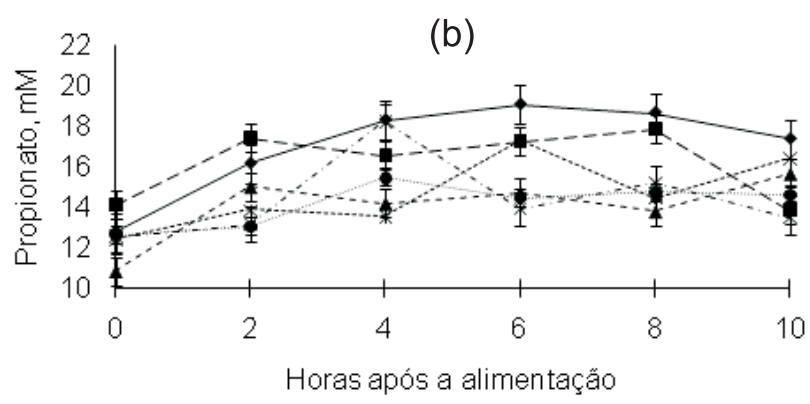

$\begin{array}{lll}\longrightarrow 0 \text { OGMSM } & --50 G M S M & \cdots 100 G M S M \\ \cdots-\cdots 0 G M S C & \cdots *-\cdots 50 G M S C & \bullet 100 G M S C\end{array}$

(d)
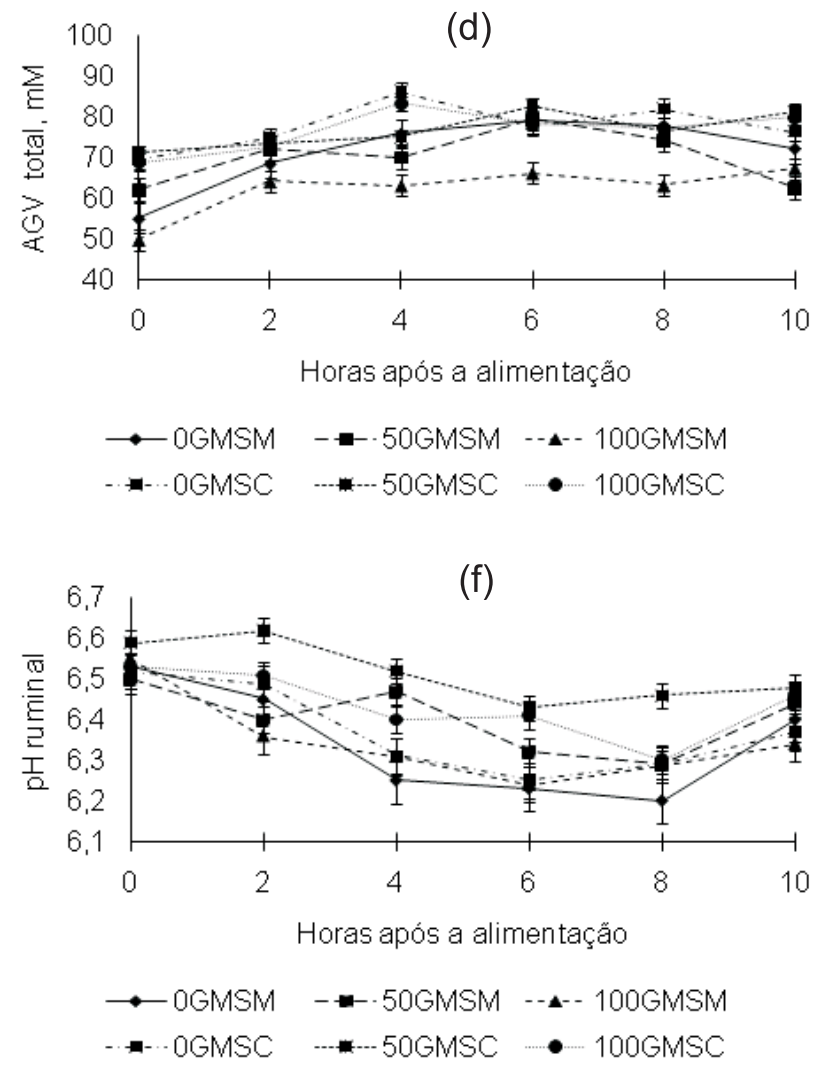

(g)

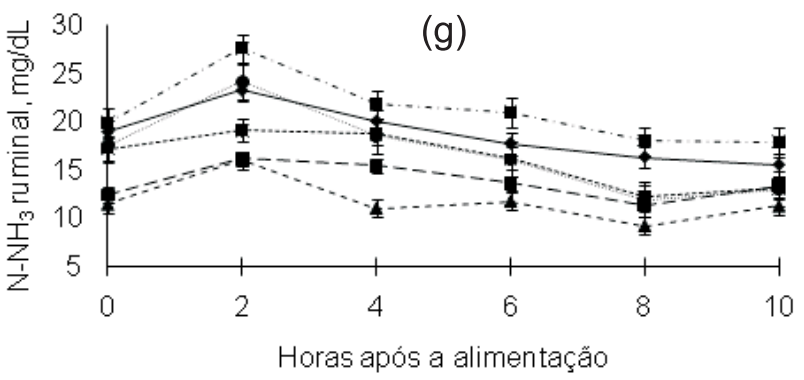

$\begin{array}{lll}\longrightarrow 0 \text { OGMSM } & -50 \text { GMSM } & -\cdots 100 G M S M \\ -0 \text { OGMSC } & -50 G M S C & \bullet 100 G M S C\end{array}$

SM: silagem de milho; SC: silagem de capim-elefante; 0GMSM: SM com inclusão total de milho; 50GMSM: SM com 50\% de substituição dos grãos de milho por grão de milheto; 100GMSM: SM com 100\% de substituição dos grãos de milho por grão de milheto; 0GMSC: SC com inclusão total de milho; 50GMSC: SC com 50\% de substituição do grão de milho por grão de milheto; 100GMSC: SC com 100\% de substituição do grão de milho por grão de milheto.

Figura 1 - Parâmetros ruminais dos bovinos alimentados com as dietas experimentais. 
as fontes de volumoso, os animais alimentados com as dietas contendo silagem de capim-elefante apresentaram maior concentração ruminal de butirato.

Não houve efeito da fonte de amido ou de volumoso sobre o pH ruminal (Tabela 4). Contudo, verificou-se que os valores mínimos de pH ocorreram entre 6 e 8 horas após o fornecimento das dietas, tendendo a aumentar após esse horário e apresentando relação inversa com a concentração dos ácidos graxos voláteis totais, uma vez que as concentrações máximas coincidiram com os menores valores de $\mathrm{pH}$ (Figuras 1d e 1f). Tais resultados estão de acordo com diversos autores (Gelaye et al., 1997; Terril et al., 1998; Ribeiro et al., 2004), os quais também não verificaram efeito da substituição do grão de milho pelo grão de milheto sobre o pH ruminal.

De acordo com Owens \& Goetsch (1988), animais alimentados com dietas ricas em volumoso apresentam valores de pH entre 6,5 e 7,0, o que favorece o desenvolvimento de microrganismos celulolíticos. No presente trabalho, apesar da elevada proporção de concentrado nas dietas (60\% da MS), o menor valor de $\mathrm{pH}$ verificado foi 6,3 para a dieta contendo apenas grãos de milho e silagem de milho, demonstrando que todos as deitas experimentais permitiram ambiente ruminal adequado para a digestão da fração fibrosa.

A substituição do grão de milho pelo grão de milheto reduziu consistentemente a concentração ruminal de $\mathrm{N}_{-} \mathrm{NH}_{3}$, independentemente da fonte de volumoso utilizada. Essa redução ocorreu porque a substituição do grão de milho pelo grão de milheto diminuiu a inclusão de farelo de soja nas dietas (Tabela 1), visto que, de acordo com o NRC (2007), o teor de proteína bruta do grão de milheto é aproximadamente $4 \%$ superior ao do grão de milho $(9,0 \%$ e $13,0 \%$, respectivamente). Segundo Tedeschi et al. (2002), o teor de proteína degradável no rúmen para o farelo de soja (69,6\% da PB) é superior ao do grão de milheto ( $64,1 \%$ da PB), fato que pode ser responsável pela redução na concentração ruminal de $\mathrm{N}-\mathrm{NH}_{3}$ com a inclusão de grãos de milheto na dieta. Os animais alimentados com as dietas contendo silagem de milho apresentaram menor concentração ruminal de $\mathrm{N}-\mathrm{NH}_{3}$ comparados aos que receberam silagem de capimelefante (Tabela 4). O pico da concentração de $\mathrm{N}_{-} \mathrm{NH}_{3}$ ruminal ocorreu duas horas após a alimentação dos animais (Figura 1g), provavelmente devido à presença de $0,5 \%$ de ureia nas dietas experimentais (Owens \& Zinn, 1988). As médias da concentração ruminal de $\mathrm{N}-\mathrm{NH}_{3}$ para todos os tratamentos foram superiores à concentração mínima de $5 \mathrm{mg} / \mathrm{dL}$, recomendada para maximizar o crescimento microbiano ruminal (Leng \& Nolan, 1984), sugerindo que não houve deficiência de $\mathrm{N}-\mathrm{NH}_{3}$ no fluido ruminal para a síntese de proteína microbiana.

\section{Conclusões}

O grão de milheto melhora a digestibilidade do extrato etéreo e do amido. Apesar de reduzir com a substituição do grão de milho pelo grão de milheto, a concentração de amônia ruminal encontra-se nos níveis satisfatórios para adequado crescimento microbiano no rúmen. Dessa forma, considerando o tipo de dieta avaliada neste estudo, o grão de milheto pode substituir totalmente o grão de milho na alimentação de bovinos de corte. A utilização da silagem de capim-elefante é eficiente, pois se assemelha à de silagem de milho para a maioria dos parâmetros de consumo, digestibilidade aparente dos nutrientes e metabolismo ruminal.

\section{Referências}

ASSOCIATION OF OFFICIAL ANALYTICAL CHEMISTS AOAC. Official methods of analysis. 16.ed. Gaithersburg: AOAC International, 1997. 1141p.

BAMPIDIS, V.A.; ROBINSON, P.H. Citrus by-products as ruminant feeds: A review. Animal Feed Science and Technology, v.128, p.175-217, 2006.

BERNARDES, T.F.; REIS, R.A.; MOREIRA, A.L. Fermentative and microbiological profile of marandu-grass ensiled with citrus pulp pellets. Scientia Agricola, v.62, n.3, p.214-220, 2005.

CAMPOS, F.P.; NUSSIO, C.M.B.; NUSSIO, L.G. Métodos de análises de alimentos. Piracicaba: FEALQ, 2004. 135p.

CHANEY, A.L.; MARBACH, E.P. Modified reagents for determination of urea and ammonia. Clinical Chemistry, v.8, n.2, p.130-137, 1962.

FERRARI JR., E.; PAULINO, V.T.; POSSENTI, R.A. et al. Aditivos em silage de capim elefante paraíso (Pennisetum hybridum cv. Paraíso). Archivos de zootecnia, v.58, n.222, p.185-194, 2009.

FIRKINS, J.L.; HRISTOV, A.N.; HALL, M.B. Integration of ruminal metabolism in dairy cattle. Journal of Dairy Science, v.89 (E Suppl.), p.E31-E51, 2006.

GELAYE, S.; TERRILL, T.; AMOAH, E.A. et al. Nutritional value of pearl millet for lactating and growing goats. Journal of Animal Science, v.75, n.5, p.1409-1414, 1997.

HILL, G.M.; HANNA, W.W. Nutritive characteristics of pearl millet grain in beef cattle diets. Journal of Animal Science, v.68, n.7, p.2061-2066, 1990

HILL, G.M.; NEWTON, G.L.; STREETER, M.N. et al. Digestibility and utilization of pearl millet diets fed to finishing beef cattle. Journal of Animal Science, v.74, n.7, p.1728-1735, 1996.

LENG, R. A.; NOLAN, J. V. Nitrogen metabolism in the rumen. Journal of Dairy Science, v.67, n.5, p.1072-1089, 1984.

LIMA, E.S.; SILVA, J.F.C.; VÁSQUEZ, H.M. et al. Produção de material seca e proteína bruta e relação folha/colmo de genótipos de capim-elefante aos 56 dias de rebrota. Revista Brasileira de Zootecnia, v.36, n.5, p.1518-1523, 2007 (supl.).

NATIONAL RESEARCH COUNCIL - NRC. Nutrient requirements of small ruminants: Sheep, goats, cervids, and new world camelids. Washington: National Academic Press, 2007. 292p.

NATIONAL RESEARCH COUNCIL - NRC. Nutrient requirements of beef cattle. 7.ed. Washington, D.C.: National Academic Press, 1996. 242p.

OWENS, F.N.; GOETSCH, A.L. Ruminal fermentation. In: CHURCH, D.C. (Ed.) The ruminant animal: digestive physiology and nutrition. Englewood Cliffs: Simon \& Schuster, 1988. cap.8, p.145-148. 
OWENS, F.N.; ZINN, R. Protein metabolism of ruminant animals. In: CHURCH, D.C. (Ed.). The ruminant animal. Englewood Cliffs: Waveland Press, 1988. chap.12, p.227-249.

POORE, M.H.; ECK, T.P.; SWINGLE, R.S. et al. Total starch and relative starch availability of feed grains. In: BIENIAL CONFERENCE ON RUMEN FUNCTION, 20., 1989, Chicago. Proceedings... Chicago, 1989. (CD-ROM).

POORE, M.H.; MOORE, J.A.; ECK, T.P. et al. Effect of fiber source and ruminal starch degradability on site and extent of digestion in dairy cows. Journal of Dairy Science, v.76, n.8, p.2244-2253, 1993.

QUEIROZ, O.C.M.; NUSSIO, L.G.; SCHMIDT, P. et al. Silagem de cana-de-açúcar comparada a fontes tradicionais de volumosos suplementares no desempenho de vacas de alta produção. Revista Brasileira de Zootecnia, v.37, n.2, p.358-365, 2008. RIBEIRO, C.V.M.; PIRES, A.V.; SUSIN, I. et al. Substituição do grão de milho pelo de milheto (Pennisetum americanum) na ração de vacas em lactação. Revista Brasileira de Zootecnia, v.33, n.5, p.1351-1359, 2004.
STATISTICAL ANALYSIS SYSTEM - SAS. User's guide: statistic. 6.ed. Cary, 1999. 956p.

TEDESCHI, L.O.; FOX, D.G.; PELL, A.N. et al. Development and evaluation of a tropical feed library for the cornell net carbohydrate and protein system model. Scientia Agricola, v.59, n.1, p.1-18, 2002.

TERRILL, T.H.; GELAYE, S.; AMOAH, E.A. et al. Protein and energy value of pearl millet grain for mature goats. Journal of Animal Science, v.76, p.1964-1969, 1998.

VAN SOEST, P.J.; ROBERTSON, J.B.; LEWIS, B.A. Methods for dietary fiber, neutral detergent fiber, and nonstarch polysaccharides in relation to animal nutrition. Journal of Dairy Science, v.74, n.10, p.3583-3597, 1991.

ZANINE, A.M.; SANTOS, E.M.; FERREIRA, D.J. et al. Características fermentativas e composição químicobromatológica de silagens de capim-elefante com ou sem Lactobacillus plantarum e farelo de trigo isoladamente ou em combinação. Ciência Animal Brasileira, v.8, n.4, p.621-628, 2007. 